\title{
Ранение и смерть А. С. Пушкина
}

\author{
Mapk Борисович Мирский
}

О ранении и последовавшей затем смерти великого русского поэта А. С. Пушкина писали многие авторы. В частности, интересный материал (по выражению автора, "судебно-медицинский очерк") А. Д. Адрианова был опубликован в сборнике статей "Из истории медицины" (Рига, 1963, т. У, c. 207-221). Однако тема эта продолжает привлекать внимание историков медицины.

Трагические обстоятельства, которые привели к ранению и смерти великого русского поэта А. С. Пушкина, дотошно исследованы пушкинистами. В разное время изучали их и писали об этом и многие медики - видные российские хирурги Н. Н. Бурденко и А. А. Арендт (правнук Н. Ф. Арендта), С. С. Юдин и А. М. Заблудовский, В. А. Шаак, Б. В. Петровский, Ш. И. Удерман, а также патолог С. М. Лукьянов, анатом В. Н. Терновский, терапевт И. А. Кассирский, другие ученые и врачи.

Напомню, что 4 ноября 1836 г. Пушкин получил анонимное письмо (полагают, что его автором был князь П. В. Долгоруков), оскорбительное для его чести и чести его жены: там был намек на Жоржа Дантеса - француза, приемного сына голландского посланника в России барона Геккерена, служившего в Петербурге офицером кавалергардского полка.

Как писал Пушкин:

"Развратник радуясь, клевещет,

Соблазн по городу гремит,

А он, хохоча, рукоплещет".

5 ноября 1836 г. Пушкин вызвал Дантеса на дуэль. Но по просьбе Геккерена дуэль была отсрочена на 15 дней и не состоялась.

Однако конфликт продолжался, и 26 января 1837 г. Дантес, только что женившийся на старшей сестре Натальи Николаевны Гончаровой - Екатерине Николаевне, вызывает Пушкина на дуэль.

Дуэли Пушкин не боялся - он был мужественный человек. Еще в апреле 1820 г. он писал: 


\footnotetext{
"Мне бой знаком - люблю я звук мечей;

От первых лет поклонник бранной славы, Люблю войны кровавые забавы,

И смерти мысль мила душе моей".
}

Дантес выбрал секундантом д’Аршиака - своего двоюродного брата, служившего атташе при французском посольстве в Петербурге. Пушкин просил быть своим секундантом Данзаса, который был его лицейским товарищем.

27 января 1837 г. на Черной речке дуэль все-таки состоялась.

Вот что рассказывал о дуэли секундант Пушкина Данзас (его рассказ был записан А. Амосовым и в 1863 г. издан отдельной брошюрой).

"Несмотря на ясную погоду, дул довольно сильный ветер. Морозу было градусов пятнадцать. Закутанный в медвежью шубу, Пушкин молчал, повидимому был столько же покоен, как и во время пути, но в нем выражалось сильное нетерпение приступить скорее к делу. Когда Данзас спросил его, находит ли он удобным выбранное им и д’Аршиаком место, Пушкин отвечал:

- Мне это совершенно безразлично, только постарайтесь сделать все возможно скорее.

Отмерив шаги, Данзас и д’Аршиак отметили барьер своими шинелями и начали заряжать пистолеты. Во время этих приготовлений нетерпение Пушкина обнаружилось словами к своему секунданту:

- Все ли, наконец, кончено?

Все было кончено. Противников поставили, подали им пистолеты, и по сигналу, который дал Данзас, махнув шляпой, они начали сходиться".

Тогда существовали две классические позиции боя, которых строго придерживались противники: первая - вытянув оружие перед собою, целясь друг в друга, противники сходятся к барьерам; вторая - поворот боком к своему противнику, прикрытие груди правой рукой, вытягивание вдоль лица дула пистолета. Вторая позиция была рассчитана на уменьшение площади прицела и на создание естественного щита.

После сигнала Данзаса дуэлянты начали сходиться.

Слово Данзасу:

"Пушкин первый подошел к барьеру и, остановясь, начал наводить пистолет. Но в это время Дантес, не дойдя до барьера одного шага, выстрелил, и Пушкин падая сказал:

- Мне кажется, что у меня раздроблена ляжка.

Секунданты бросились к нему, и когда Дантес намеревался сделать то же, Пушкин удержал его словами:

- Подождите, у меня еще достаточно силы, чтобы сделать свой выстрел.

Дантес остановился у барьера и ждал, прикрыв грудь правою рукою.

При падении Пушкина пистолет его попал в снег, и поэтому Данзас подал ему другой. 
Приподнявшись несколько и опершись на левую руку, Пушкин выстрелил. Дантес упал.

На вопрос Пушкина у Дантеса: куда он ранен? - Дантес отвечал:

- Я думаю, что ранен в грудь.

- Браво! - вскрикнул Пушкин и бросил пистолет в сторону.

Но Дантес ошибся: он стоял боком, и пуля, только контузив его грудь, попала в руку.

Пушкин был ранен в правую сторону живота, пуля, раздробив кость верхней части ноги у соединения с тазом, глубоко вошла в живот и там остановилась".

Итак, Пушкин подошел к барьеру, остановился, вытянул корпус вперед и сосредоточенно стал целиться: в это время и грянул выстрел.

Вот как об этом писал в своих стихах Михаил Лермонтов:

"Его убийца хладнокровно

Навел удар... спасенья нет:

Пустое сердце бьется ровно,

В руке не дрогнул пистолет".

Да, пистолет Дантеса не дрогнул; он первым произвел свой выстрел, не дойдя до барьера одного шага, то есть, он стрелял с расстояния одиннадцати шагов. Выстрел его прогремел для Пушкина неожиданно, - он в это время целился в Дантеса, правый бок его был открыт и не защищен (правой рукой он прицеливался).

Как выяснилось впоследствии, пуля проникла в живот Пушкина на два дюйма (5 cм) внутри от передней верхней ости правой подвздошной кости. Свинцовая пуля, ударившись о подвздошную кость, причинила, как говорилось во врачебном заключении, "взрыв подвздошной кости", тяжело ранила ткани и застряла в раздробленном крестце. Кроме того, произошел ушиб кишки (тонкого кишечника) осколком кости, там развился "раневой перитонит".

После ранения Пушкин упал на левый бок, сам приподнялся с земли, взял другой пистолет, и, сидя и опершись на левую руку, правой прицелился в Дантеса, выстрелил, снова упал.

Вновь слово секунданту Пушкина Данзасу:

"Данзас с д'Аршиаком подозвали извозчиков и с помощью их разобрали находившийся там из тонких жердей забор, который мешал саням подъехать к тому месту, где лежал раненый Пушкин. Общими силами усадив его бережно в сани, Данзас приказал извозчику ехать шагом, а сам пошел пешком подле саней вместе с д’Аршиаком; раненый Дантес ехал в своих санях за ними.

У Комендантской дачи они нашли карету, присланную на всякий случай бароном Геккереном-отцом. Дантес и д’Аршиак предложили Данзасу отвезти в ней в город раненого поэта. Данзас принял это предложение. Не 
сказав, что карета была барона Геккерена, Данзас посадил в нее Пушкина и, сев с ним рядом, поехал в город. Во время дороги Пушкин держался довольно твердо, но, чувствуя по временам сильную боль, он начал подозревать опасность своей раны.

Пушкин вспомнил про дуэль общего знакомого их Щербачева, который был смертельно ранен в живот и, жалуясь на боль, сказал Данзасу: "Я боюсь, не ранен ли я так, как Щербачев". Пушкин в особенности беспокоился о том, чтобы по приезде домой не испугать жены".

Карета приехала на набережную Мойки и здесь остановилась у дома Волконского - Пушкин жил в нижнем этаже этого дома. У подъезда раненый поэт попросил вынести его из кареты и, если жена его дома, то предупредить ее и сказать, что рана не опасна.

Вот что вспоминал Данзас:

"В передней люди сказали Данзасу, что Натальи Николаевны не было дома, но когда Данзас сказал им, в чем дело, и послал их вынести раненого Пушкина из кареты, они объявили, что госпожа их дома. Данзас через столовую, в которой накрыт уже был стол, и гостиную пошел прямо без доклада в кабинет жены Пушкина. Она сидела со своей незамужней сестрой Александрой Николаевной Гончаровой. Внезапное появление Данзаса очень удивило Наталью Николаевну, она взглянула на него с выражением испуга, как бы догадываясь о случившемся.

Данзас сказал ей, сколько мог покойнее, что муж ее стрелялся с Дантесом, что хотя ранен, но очень легко.

Она бросилась в переднюю, куда в это время люди вносили Пушкина на руках.

Увидя жену, Пушкин начал ее успокаивать, говоря, что рана его вовсе не опасна, и попросил уйти, прибавив, что как только его уложат в постель, он сейчас же позовет ее.

Она, видимо, была поражена и удалилась как-то бессознательно".

Но возвратимся к месту дуэли. Когда Пушкин упал, его подняли с земли, вначале пытались "тащить" к саням, но потом уложили на шинель и понесли к саням. В сани его - раненого, с раздробленным переломом костей таза - не уложили, а усадили, и затем по тряской, очень плохой дороге везли полверсты, и только потом пересадили в карету и повезли домой. Здесь уже камердинер Никита Козлов принял его, поднял из кареты и "охапкой на руках" понес на лестницу. Затем Пушкина внесли в кабинет, там он разделся и, с помощью других, лег на диван.

Как полагали многие, что во время двукратного падения и транспортировки от места ранения до дивана в кабинете вполне могло произойти повреждение стенки кишки маленьким осколком кости с острым краем.

Почему же раненому Пушкину на месте дуэли не оказали никакой помощи? 
Дело в том, что о поединке между Пушкиным и Дантесом никто не знал. А те, кому Пушкин поведал о своих намерениях (сестра жены А. Н. Гончарова, его добрые приятельницы сестры Осиповы), держали это втайне.

Теперь уже не секрет, что Пушкин вел подготовку к дуэли в состоянии большого нервного напряжения. Он знал, конечно, что нарушает строгий запрет на дуэли, введенный еще законом императора Петра I от 14 января 1702 г., предусматривавшем смертную казнь через повешение за участие в дуэли, и поэтому, естественно, не хотел вовлекать родных и знакомых в это подследственное дело.

Поединок с Дантесом был четвертым в жизни Пушкина (три закончились примирением). И в этот раз внимание Пушкина было настолько сильно сконцентрировано на расплате за оскорбленное чувство, что это вытеснило всякие мысли об организации первой помощи.

А что же Данзас? Ведь секундант Пушкина должен был подумать о самых элементарных средствах первой помощи на случай серьезного ранения своего друга, позаботиться хотя бы об удобных санях, самодельных носилках, жгуте и бинтах. Почему он оказался так беспечен?

Как выяснилось впоследствии из показаний Данзаса на допросе в специальной военно-судной комиссии (её создали по приказу императора Николая I), Пушкин предложил ему стать секундантом в день дуэли, за несколько часов до поединка. Много времени он потратил на то, чтобы уладить условия поединка с секундантом Дантеса д’Аршиаком. И хотя у Данзаса временами возникала мысль о возможном примирении между противниками, но Пушкин настойчиво и решительно противился этому. По условиям дуэли Данзас понимал, насколько серьезен был предстоящий поединок; но, будучи втянут в водоворот событий, он просто не имел возможности подумать о возможности первой помощи для своего друга.

Сколько времени заняла перевозка Пушкина с места ранения на Черной речке до квартиры на набережной Мойки?

Подсчитано, что длина пути, по которому Пушкин с Данзасом ехали на дуэль, равна 7,5 верстам. Это была самая кратчайшая дорога на Черную речку. Обратный путь проходил по той же дороге. Полверсты Пушкин с Данзасом добирались по самой плохой дороге от места дуэли до Комендантской дачи, там Пушкина пересадили в карету. Всего в пути они были около часа. Так как состояние раненого поэта было тяжелым, приходилось делать короткие остановки.

...После ранения Пушкин прожил 46 часов 15 минут.

Вот врачебная хроника этих последних двух суток жизни поэта, его ранения и болезни.

Om 4 до 5 часов дня 27 января 1837 года. Дуэль. Ранение. Сильный удар в бок, ощущение чего-то горячо стрельнувшего в поясницу. Ноги "подкосились", все тело как бы рухнуло, Пушкин упал лицом в снег и потерял созна- 
ние, а когда очнулся, сидя произвел ответный выстрел. Повторное падение тела животом на шинель, лицом в снег. Потеря сознания на "несколько минут". Сильное кровотечение из небольшой раны в правой половине живота. Бледность лица, кистей рук, "расширенный взгляд". Окровавленная одежда. След крови по дороге к саням.

Om 5 до 6 часов вечера. Раненый находится в пути. Жалобы на сильную боль в области ранения, мучительную тошноту. Прерывистые фразы; кратковременные обмороки. Пушкина внесли в квартиру на руках и положили на диван.

Слово Данзасу:

"Он (Данзас - М. М.) отправился за доктором. Сначала поехал к Арендту, потом к Саломону; не застав дома ни того, ни другого, оставил им записки и отправился к доктору Персону, но и тот был в отсутствии. Подъезжая к воспитательному дому, Данзас встретил выходившего из ворот доктора Шольца. Тот сказал ему, что он как акушер в этом случае полезным быть не может, но что сейчас привезет к Пушкину другого доктора.

Вернувшись назад, Данзас нашел Пушкина в его кабинете, уже раздетого и уложенного на диване; жена его была с ним. Вслед за Данзасом приехал и Шольц с доктором Задлером. Когда Задлер осмотрел рану и наложил компресс, Данзас, выходя с ним из кабинета, спросил его, опасна ли рана Пушкина. "Пока еще ничего нельзя сказать", - отвечал Задлер".

Кто были Шольц и Задлер?

Вильгельм Шольц после окончания Санкт-Петербургской медикохирургической академии в августе 1818 г. поступил в Ревельский Морской госпиталь старшим лекарем. За "важные операции" ему было присвоено звание медико-хирурга и он перешел в Петербургский Адмиралтейский госпиталь. Впоследствии стал известным акушером-гинекологом, профессором повивального училища воспитательного института. Шольца награждали разными орденами, за "ревностные заслуги" сделали дворянином.

Карл Карлович Задлер (1801-1877) родился в Гааге, но потом, получив медицинское образование, приехал в Россию. Он стал придворным врачом был главным врачом придворного конюшенного госпиталя, расположенного по набережной Мойки, и имел прямое отношение к хирургии, впоследствии был дружен с Н. И. Пироговым.

Слово Шольцу:

"27 января в 6 1/4 ч. полковник Данзас пригласил меня к трудно раненному Александру Сергеевичу Пушкину.

Прибывши к больному с доктором Задлером (перед приездом к Пушкину тот был у Дантеса и перевязал ему рану), которого я дорогою сыскал, взошли в кабинет больного, где нашли его лежащим на диване и окруженным тремя лицами: супругою, полковником Данзасом и г-м Плетневым. Больной просил удалить и не допустить при исследовании раны жену и прочих домаш- 
них. Увидев меня, дал мне руку и сказал: "Плохо со мною". Мы осматривали рану, и г-н Задлер уехал за нужными инструментами.

Больной громко и ясно спрашивал меня: "Что вы думаете о моей ране; я чувствовал при выстреле сильный удар в бок и горячо стрельнуло в поясницу. Дорогою шло много крови. Скажите мне откровенно, как вы рану находили?"

- Не могу вам скрывать, что рана ваша опасная.

- Скажите мне - смертельная?

- Считаю долгом вам это не скрывать, но услышим мнение Арендта и Саломона, за которыми послано.

- Благодарю вас, что вы сказали мне правду как честный человек. Теперь займусь делами моими (при сем рукою потер себе лоб).

Через несколько минут сказал: "Мне кажется, что много крови идет?"

Я осмотрел рану, но нашлось, что мало - и наложил новый компресс.

- Не желаете ли вы видеть кого-нибудь из близких приятелей?

- Прощайте, друзья! - (сказал он, глядя на библиотеку). - Разве Вы думаете, что я часу не проживу?

- О нет, не потому, но я полагаю, что Вам приятнее кого-нибудь из них видеть... Г-н Плетнев здесь...

- Да, - но я бы желал Жуковского. - Дайте мне воды, меня тошнит.

Я трогал пульс, нашел руку довольно холодною - пульс малый, скорый, как при внутреннем кровотечении; вышел за питьем и чтобы послать за г-м Жуковским. Полковник Данзас вошел к больному. Между тем приехал Задлер, Арендт, Саломон, и я оставил печально больного, который добродушно пожал мне руку".

Врачебная хроника болезни:

Om 6 до 7 часов вечера. Раненый несколько возбужден. Жалобы на тошноту. Беспокоен; ощущение жажды. Сознание ясное. Пульс слабый, частый, холодный пот, конечности холодные. Кровотечение из брюшной раны небольшое.

Om 7 до 11 часов вечера. Состояние тяжелое. Жалобы на боли в животе. Сознание ясное. Кратковременное "забытье" (беспамятство). Троекратное пребывание доктора Арендта.

Чтобы составить картину происходившего у постели раненого Пушкина, необходимо напомнить, кто был Н. Ф. Арендт.

Николай Федорович Арендт (1785-1859) родился в Казани: его дед был ремесленником, мастером медных дел, а отец, уроженец Москвы Федор Ивасковской полиции. Младший брат Андрей (1795-1862) тоже впоследствии стал штаб-лекарем, инспектором врачебной управы Таврической губернии.

Арендт учился в Петербургской медико-хирургической академии, которую "блистательно окончил" в 1805 г., получив звание кандидата хирургии, а в награду за отличные успехи в ученье - серебряный карманный набор 
хирургических инструментов (соответствовал учрежденной позднее золотой медали). После продолжительной стажировки в Петербургском генеральном госпитале в 1806 г. его назначили лекарем в Навагинский мушкетерский полк; в рядах этого, а затем и других русских полков, он участвовал во многих сражениях (наполеоновские войны, война со Швецией), стал штаблекарем, а затем лекарем I-го класса, приобрел большой опыт, проделав более 800 военно-полевых операций.

В 1812 г. он был назначен дивизионным доктором 13-й пехотной дивизии, потом штаб-доктором І-го пехотного корпуса, а в 1814 году, после взятия Парижа, - главным врачебным инспектором находившихся тогда во Франции русских войск. Возвратившись в 1815 г. в Россию, Арендт вновь стал дивизионным доктором, а затем - старшим доктором кавалерии гвардейского корпуса. В 1820 г. его назначили главным доктором артиллерийского госпиталя в Петербурге: на время работы в этом госпитале пришелся расцвет его научно-практической деятельности как хирурга и ученого. Высокое научно-практическое мастерство Н. Ф. Арендта получило всеобщее признание ученых-медиков и медицинской общественности, что нашло выражение в беспрецедентном в истории российской медицины акте: "за усердную и долговременную службу, равно как и за совершенное познание медицины и хирургии, доказанное многократным производством всех операций", Н. Ф. Арендту в 1821 г. без сдачи обязательного экзамена и без защиты диссертации была присвоена ученая степень доктора медицины и хирургии.

В 1827 г. он ушел в отставку с военной службы и занялся широкой медицинской практикой, в основном хирургической. Вскоре его пригласили на должность главного консультанта в Обуховскую больницу: многие годы там он работал бесплатно. По должности "главного доктора Петербургского приказа общественного призрения" он бесплатно лечил петербургскую бедноту, снабжал своих пациентов бесплатными лекарствами, а часто и пищей. По отзывам современников, Н. Ф. Арендт был самым популярным и самым общедоступным врачом северной столицы - Петербурга. Вот что говорил об Н. Арендте Н. И. Пирогов: "Очень смелый и предприимчивый хирург, большой врач-практик. Занятый на этой работе с утра до позднего времени, любимый за доброту души". Он славился как искусный и смелый хирург; считалось, что тайна неимоверного успеха его операций в значительной степени коренится в тщательном уходе, которым он окружал больного после сделанной операции.

После успешного лечения императора Николая I Арендт в 1829 году был назначен лейб-медиком и в течение 10 лет исполнял обязанности его личного врача. Кроме того, он лечил А. С. Пушкина, М. Ю. Лермонтова и других выдающихся деятелей русской культуры. С 1844 г. он был помощником медицинского инспектора, а с 1847 г. - инспектором лечебных учреждений 
ведомства императрицы Марии. Арендт всегда благожелательно относился к молодым хирургам, одним из первых оценил и поддерживал талант молодого Н. И. Пирогова. Позднее вместе с Н. И. Пироговым, а также с И. В. Буяльским, X. Х. Саломоном и другими хирургами он участвовал во врачебных консилиумах.

Арендт внес весомый вклад в хирургию. В Петербургском артиллерийском госпитале он выполнил свои знаменитые операции - экзартикуляции целых конечностей и особенно перевязки кровеносных сосудов по поводу аневризм, ставшие широко известными в России и за рубежом. Так, он впервые в России перевязал общую сонную, наружную подвздошную, безымянную и подключичную артерии (последнюю вместе с д-ром Гибсом), Некоторые из этих операций (например, перевязку безымянной артерии) он сделал первым в нашей стране, а перевязку аневризмы наружной подвздошной артерии - первым в мире. Впервые в России он произвел операцию тенотомии. Он производил и другие весьма сложные вмешательства, например, впервые произвел вылущение в плечевом суставе по Лисфранку и вылущение стопы по Шопару.

Хотя Арендт не оставил больших научных трудов, его обстоятельные описания главнейших хирургических операций представляют ценный вклад в медицинскую науку и по праву вошли в специальные руководства по хирургии. Еще будучи с оккупационным корпусом в Париже, Арендт прочитал в аудиториях Сорбонны курс лекций по военно-полевой хирургии. Его обзор операций был настоящим триумфом русской медицинской школы и поставил имя Арендта наряду со знаменитыми именами Грефе, Купера, Лисфранка.

В общем, это был врач с большой буквы. Он почти не отходил от постели раненого Пушкина, а в день смерти Пушкина первым рано утром рассказал другому своему пациенту, поэту М. Ю. Лермонтову, о последних часах жизни его кумира...

Хотя именно Н. Ф. Арендт руководил лечением Пушкина, он не оставил никаких воспоминаний о ранении, лечении и смерти поэта. И очень трудно сказать, почему: то ли должность лейб-медика не позволила ему это сделать, то ли потому, что он вообще писал немного.

Зато другие врачи, лечившие Пушкина, друзья поэта в своих воспоминаниях очень часто упоминают Н. Ф. Арендта, подчеркивают его авторитетное и руководящее участие, приводят его высказывания о течении болезни Пушкина и прогнозе, можно сказать, ловят каждое слово, даже случайно пророненное Арендтом.

Например, приятель поэта В. П. Бурнашев приводит слова Н. Ф. Арендта, когда он вышел из квартиры А. С. Пушкина. На вопрос: "Ну что, ваше превосходительство?", он ответил: "Ну то, что очень плохо! Наша вся медицина ничего не сделает без царя Небесного". 
Свидетельствует Данзас:

"В это время приехал Арендт, он также осмотрел рану. Пушкин просил его сказать ему откровенно, в каком он его находит положении, и прибавил, что какой бы ответ ни был, он его испугать не может, но что ему необходимо знать наверное свое положение, чтобы успеть сделать некоторые нужные распоряжения.

- Если так, - отвечал ему Арендт, - то я должен вам сказать, что рана ваша очень опасна и что к выздоровлению вашему я почти не имею надежды.

Пушкин благодарил Арендта за откровенность и просил только не говорить жене".

Надо сказать, что Пушкин, обычно веселый и жизнерадостный, нередко все-таки задумывался о смерти. Вот его известные стихи, написанные в декабре 1829:

"Брожу ли я вдоль улиц шумных, Вхожу ли во многолюдный храм, Сижу ль меж юношей безумных, Я предаюсь моим мечтам...

День каждый, каждую

Привык я думой провожать,

Грядущей смерти годовщину

Меж их стараюсь угадать.

И где мне смерть пошлет судьбина?

В бою ли, в странствии, в волнах?

Или соседняя долина

Мой примет охладелый прах?"

Но вернемся к постели раненого поэта.

Итак, снова Данзас:

"Прощаясь Арендт объявил Пушкину, что по обязанности своей он должен доложить обо всем случившемся государю.

Пушкин ничего не возразил против этого, но поручил только Арендту просить от его имени государя не преследовать его секунданта.

Уезжая Арендт сказал провожавшему его в переднюю Данзасу:

- Штука скверная, он умрет".

Вечером 27 января к раненому Пушкину приехал домашний врач семьи доктор Спасский.

Иван Тимофеевич Спасский (1795-1859) окончил Петербургскую медико-хирургическую академию в 1815 г. с золотой медалью, а потом, поработав ординатором Адмиралтейского госпиталя, в течение нескольких лет совершенствовался в клиниках Эдинбурга, Лондона, Берлина, Вены. По возвращении в Россию он снова работал в Адмиралтейском госпитале, стал доктором медицины и хирургии, профессором Петербургской медико- 
хирургической академии. Спасский был вдумчивым и опытным клиницистом, имел в Петербурге большую практику, в том числе был домашним врачом семьи А. С. Пушкина. Энциклопедически образованный ученый, он был автором многих научных трудов, членом ряда научных обществ, в т. ч. Берлинского Медико-хирургического общества.

Много фактов указывают на большое доверие, уважение Пушкина к Спасскому. Например, в апреле 1834 г. в письме к жене Пушкин писал: "... сделай милость, не забудь прочесть инструкцию Спасского и поступай по оной...", "...не смей купаться... послезавтра обедаю у Спасского и буду на тебя жаловаться...". В мае в письме к ней: "...говорил я со Спасским о Пирмонтских водах, он желает, чтобы ты их принимала, и входил со мною в подробности, о которых по почте не хочу писать". В других письмах Пушкин просил жену показаться доктору Спасскому. Пушкин подарил Спасскому свою трость с серебряным набалдашником в знак благодарности.

Вот что вспоминал доктор Спасский:

"В 7 часов вечера, 27 числа минувшего месяца, приехал за мною человек Пушкина. Александр Сергеевич очень болен, приказано просить как можно поскорее. Я не медля отправился. В доме больного я нашел доктора Арендта и Задлера. С изумлением я узнал об опасном положении Пушкина. "Что, плохо?" - сказал мне Пушкин, подавая руку. Я старался его успокоить. Он сделал рукою отрицательный знак, показывающий, что он ясно понимает опасность своего положения. "Пожалуйста, не давайте больших надежд жене, не скрывайте от нее, в чем дело; она не притворщица, вы ее хорошо знаете, она должна все знать. Впрочем - делайте со мною, что вам угодно, я на все согласен и на все готов".

Врачи, уехав, оставили на мои руки больного. Он исполнял все врачебные предписания. По желанию родных и друзей Пушкина, я сказал ему об исполнении христианского долга. Он тот же час на то согласился. Прибыл священник: больной исповедовался и причастился. От времени до времени он тихо жаловался на боль в животе и забывался на короткое время".

Современники вспоминали, что Арендт был поражен мужеством, с которым переносил свои страдания умирающий поэт. "Арендт, который видел много смертей на веку своем и на полях сражений, и на болезненных одрах, - писал П. А. Вяземский, - отходил со слезами на глазах от постели его и говорил, что он никогда не видел ничего подобного, такого терпения при таких страданиях".

Вместе с Арендтом тяжело переживал страдания раненого Пушкина его домашний доктор И. Т. Спасский.

На долю Спасского выпало наблюдение и лечение Пушкина в первый, самый напряженный период его болезни. Через час с лишним после ранения доктор Спасский приехал к нему и с семи часов вечера и до одиннадцати 
утра следующего дня он не отходил от него: шестнадцать часов неотлучного бдения.

Вот что свидетельствовала врачебная хроника:

Om 11 до 3 часов ночи с 27 на 28 января. Состояние тяжелое. Бессоница. Кратковременное "забытье". Боль в животе нарастает; стонет, иногда кричит от боли в животе.

Om 3 до 7 часов утра 28 января. Боль в животе резко нарастает. Состояние тяжелое. Кричит от боли в животе. Вздутие живота.

Снова Данзас:

"Перед вечером Пушкин, позвав Данзаса, попросил его записывать и продиктовал ему все свои долги, на которые не было ни векселей, ни заемных писем.

Потом он снял с руки кольцо и одел Данзасу, прося принять его на память...

Вечером ему сделалось хуже. В продолжение ночи страдания Пушкина до того усилились, что он решился застрелиться. Позвав человека, он велел подать ему один из ящиков письменного стола; человек исполнил его волю, но, вспомнив, что в этом ящике были пистолеты, предупредил Данзаса.

Данзас подошел к Пушкину и взял у него пистолеты, которые тот уже спрятал под одеяло; отдавая их Данзасу, Пушкин признался, что хотел застрелиться потому, что страдания его были невыносимы".

А теперь доктор Спасский:

"Доктор А. (Арендт - М. М.) приехал в 11 часов. В лечении не последовало перемен. Уезжая доктор А. просил меня тотчас прислать за ним, если я найду то нужным. Около четвертого часу боль в животе начала усиливаться, и к пяти часам сделалась значительною. Я послал за А., он не замедлил приехать. Боль в животе возросла до высочайшей степени. Это была настоящая пытка.

Физиономия Пушкина изменилась, взор его сделался дик, казалось, глаза готовы были выскочить из своих орбит, тело покрылось холодным потом, руки похолодели, пульса как не бывало. Больной испытывал ужасную муку. Но и тут необыкновенная твердость его души раскрылась в полной мере. Готовый вскрикнуть, он только стонал, боясь, как он говорил, чтобы жена не услышала, чтоб ее не испугать.

Наконец боль, по-видимому, стала утихать, но лицо еще выражало глубокое страдание, руки по-прежнему были холодны, пульс едва заметен. "Жену, просите жену", - сказал Пушкин. Она с воплем горести бросилась к страдальцу. Это зрелище у всех извлекло слезы.

Я спросил его, не хочет ли он видеть своих друзей. "Зовите их", - отвечал он. Жуковский, Виельгорский, Вяземский, Тургенев и Данзас входили один за другими и братски с ним прощались. Потребовал детей и благословил каждого особенно. Я взял больного за руку и щупал его пульс. Когда я оста- 
вил его руку, то он сам приложил пальцы левой своей руки к пульсу правой, томно, но выразительно взглянул на меня и сказал: "Смерть идет". Он не ошибался, смерть летала над ним в это время. В 11-м часу утра я оставил Пушкина на короткое время, простился с ним, не полагая найти его в живых по моему возвращении. Место мое занял другой врач", - это был доктор Андреевский.

Ефим Иванович Андреевский в Петербурге считался одним из опытнейших врачей-практиков. Был доктором медицины и хирургии, президентом Петербургского Общества русских врачей.

\section{Врачебная хроника.}

Ночь 28 января. Приехал доктор Арендт. Поставил клизму ("промывательное"). Не подействовала. Состояние резко ухудшилось; изменилось лицо, "дикий" взор - глаза как бы вышли из орбит; холодный пот; похолодание конечностей, пульса нет; мучительные стоны. Сознание сохранено. Больной не в состоянии говорить.

Om 7 до 11 часов утра. Состояние тяжелое. Прием лекарства. Вздутие живота держится. Боль несколько стихла. Холодные конечности; пульс едва прощупывается. Сознание сохранено.

Снова Данзас:

"Во все время болезни Пушкина передняя его постоянно была наполнена знакомыми и незнакомыми вопросы: "Что Пушкин? Легче ли ему? Поправится ли он? Есть ли надежда?" - сыпались со всех сторон.

У подъезда была давка.

В передней какой-то старичок сказал с удивлением:

- Господи боже мой! Я помню, как умирал фельдмаршал, а этого не было!

Пушкин впускал к себе только самых коротких своих знакомых, хотя всеми интересовался, беспрестанно спрашивал, кто был у него в доме, и говорил: "Мне было бы приятно видеть их всех, но у меня нет силы говорить с ними". По этой причине, вероятно, он не простился и с некоторыми из своих лицейских товарищей.

К полудню Пушкину сделалось легче, он несколько развеселился и был в духе. Около часу приехал доктор Даль. Пушкин просил его войти и, встречая его, сказал:

- Мне приятно вас видеть не только как врача, но и как родного мне человека по нашему общему литературному ремеслу.

Он разговаривал с Далем и шутил".

Кто был В. И. Даль, известный больше всего как автор четырехтомного словаря русского языка?

Владимир Иванович Даль родился в Луганске. Его отец, датчанин Иоганн Даль, был врачом и в свое время окончил Иенский университет, служил в России в качестве главного доктора Черноморского флота. Сам В. И. Даль окончил Медицинский факультет Дерптского университета, был военным 
врачом, работал в госпитале, успешно делал глазные операции, увлекался гомеопатией. В 1833 г. он оставил медицину, стал чиновником - помощником генерала Перовского в Оренбурге, потом в Петербурге. Даль прославился как писатель (псевдоним Казак Луганский) и, главным образом, как автор "Толкового словаря живого великорусского языка".

С Пушкиным Даль познакомился через Жуковского. Первая встреча произошла в 1832 г., а вторая - в 1833 г. в Оренбурге, куда Пушкин приехал собирать материалы, связанные с восстанием Пугачева. Будучи в Петербурге, Даль случайно узнал о ранении Пушкина и через сутки после дуэли явился на его квартиру. Когда он туда пришел, доктор Арендт и доктор Спасский "пожимали плечами". Таким образом, Даль случайно оказался лечащим врачом Пушкина. Однако с этого времени до самой смерти Пушкина он оставался в его доме и отлучался только на несколько минут. Пушкин не был коротко знаком с Далем и говорил ему "вы"; в последние минуты начал говорить "ты".

Врачебная хроника.

Om 11 до 12 часов дня. Приехал доктор Арендт. После приема опийных капель Пушкин несколько успокоился.

Om 12 до 2 часов дня. Больному чуть лучше. Согрелись руки. Появился пульс. На живот вместо холодных компрессов стали класть "мягчительные" припарки. Появились проблески жизни. Больной стал немного активнее.

Om 2 до 5 часов. Больной страдает меньше, но состояние тяжелое.

Вспоминает доктор Спасский:

"По возвращении моем в 12 часов пополудни мне казалось, что больной стал спокойнее: руки его были теплее и пульс явственнее. Он охотно брал лекарства, заботливо спрашивал о жене и о детях. Я нашел у него доктора Даля. Побыв у больного до 4-го часу, я снова его оставил на попечение доктора Даля".

Говорит Данзас:

"В комнате были некоторые из друзей Пушкина и несколько докторов, между которыми был и Арендт. Окружающие, видя веселое расположение Пушкина, начали надеяться или, по крайней мере, желали, чтобы болезнь приняла более благоприятный оборот. Эти надежды казались тем основательнее, что сами доктора перестали отвергать ее; по крайней мере они говорили друзьям Пушкина, что предположения медиков иногда бывают ошибочными, что, несмотря на их решение, Пушкин может быть и поправится. Они нашли полезным поставить ему пиявки. Пушкин сам помогал их ставить, смотрел, как они принимались, и приговаривал:

- Вот это хорошо, это прекрасно.

Через несколько минут потом Пушкин, глубоко вздохнув, сказал:

- Как жаль, что нет теперь здесь ни Пущина, ни Малиновского, мне бы легче было умирать". 
Но Пушкин, конечно же, не хотел умирать. Он мог бы повторить свои стихи:

"Но не хочу, о други, умирать;

Я жить хочу, чтоб мыслить и страдать;

И ведаю, мне будут наслажденья

Меж горестей, забот и треволнения".

Накануне 28 января, как вспоминает Данзас, у Пушкина побывало несколько докторов - вероятно, их пригласил Арендт. Это были прежде всего профессора И. В. Буяльский и Х. Х. Саломон.

Напомню, что Илья Васильевич Буяльский был крупнейшим ученымхирургом, профессором Петербургской медико-хирургической академии, европейской знаменитостью. Он прославился своими пионерскими операциями на кровеносных сосудах, другими операциями. Его труд "Анатомикохирургические таблицы" (1828) был переведен, в частности, на немецкий язык: труд этот высоко оценили Лангенбек, Гуфеланд и др. Более 30 лет был консультантом крупнейшей в Петербурге Мариинской больницы. Буяльского по праву считали опытнейшим врачом-клиницистом, мастером диагноза, часто приглашали на консилиумы и консультации.

Крупным клиницистом и хирургом был и Христиан Христианович Саломон. Он родился в Нарве, окончил медико-хирургическую академию с золотой медалью, совершенствовался в Лондоне, Эдинбурге, Гёттингене, Берлине и Вене. В Петербурге он стал профессором медико-хирургической академии. Главные труды Саломона посвящены офтальмологии, венерологии, собственно хирургии (особенно лечению грыж и болезней суставов), урологии, травматологии. Он был лауреатом Демидовской премии и пользовался большой известностью как клиницист.

Слово доктору Далю:

"28-го января у Пушкина нашел я толпу в зале и в передней - страх ожидания пробегал шепотом по бледным лицам. Г. г. Арендт и Спасский пожимали плечами. Я подошел к болящему - он подал мне руку, улыбнулся и сказал: "Плохо, брат!".

Грустное, меланхоличное настроение предвосхищение собственной гибели вызывает в памяти стихи Пушкина, написанные незадолго до этого:

"Пора, мой друг, пора! Покоя сердце просит -

Летят за днями дни, и каждый час уносит

Частичку бытия...".

Вспоминает д-р Даль:

"Я присел к одру смерти - не отходил до конца страстных суток. В первый раз Пушкин сказал мне "ты". Я отвечал ему так же - и побратался с ним за сутки до смерти его, уже не для здешнего мира!

Пушкин заставил всех присутствовавших сдружиться со смертью, так спокойно он ее ожидал, так твердо был уверен, что роковой час ударил. 


\section{М. Б. Мирский}

Пушкин положительно отвергал утешение наше и на слова мои: "Все мы надеемся, не отчаивайся и ты!", отвечал: "Нет, мне здесь не житье; я умру, да видно уж так и надо!". В ночь на 29-е он повторял несколько раз подобное, спрашивал, например: "Который час?", и на ответ мой продолжал отрывисто и с расстановкой: "Долго ли мне так мучиться?! Пожалуйста, поскорей!".

А вот что писал д-р Спасский:

"Я возвратился к нему около 7 часов вечера. Я нашел, что у него теплота в теле увеличилась, пульс сделался гораздо явственнее и боль в животе ощутительнее. Больной охотно соглашался на все предлагаемые ему пособия. Он часто требовал холодной воды, которую ему давали по чайным ложечкам, что весьма его освежало. Так как в эту ночь предложил остаться при больном Д. Д., то я оставил Пушкина около полуночи".

\section{Врачебная хроника.}

Om 5 до 6 часов вечера. Состояние продолжало оставаться тяжелым. Пульс "крайне мал, слаб и част". Лекарства - лавровишневая вода, каломель. Больной более или менее спокоен.

Небольшой "общий жар". Пульс 120 в одну минуту, полный, твердый. Усилилось беспокойство больного. "Начало образовываться воспаление". "Припустили" к животу 25 пиявок.

Om 7 до 11 часов вечера 28 января. Состояние слабости. Стихла "лихорадка", уменьшение жара, "опал живот, кожное испарение", пульс стал ровнее и мягче. Дали касторку. Больной не спит. Чувство тоски. Боли продолжаются. Частое отрывистое дыхание. Тихо стонет. Сознанье сохранено.

От 12 часов ночи и позже, в течение ночи с 28-го на 29-е января. Пульс стал падать с часу на час. Общее изнеможение. Изменилось лицо. Остыли руки. Ноги теплые. Трудно разговаривать из-за нарастающей слабости. Чувство тоски.

Как писал в эти часы приятель поэта А. И. Тургенев с квартиры Пушкина: "Полдень. Арендт сейчас был. Надежды нету, хотя есть облегчение страданиям. Арендт думает, что это не протянется до вечера. А ему должно верить; он видел смерть в 34 битвах".

Снова вспоминает доктор Даль:

"Почти всю ночь продержал он меня за руку, почасту брал ложечку водицы или крупинку льда и всегда при этом управлялся своеручно: брал стакан сам с ближней полки, тер себе вески льдом, сам сымал и накладывал себе на живот припарки; собственно, от боли страдал он, по словам его, не столько, как от чрезмерной тоски. "Ах, какая тоска!" - восклицал он иногда, закидывая руки на голову, - "сердце изнывает!"

Вероятно, в таком же настроении, обуреваем тоской, был Пушкин, когда написал известное стихотворение:

"Дар напрасный, дар случайный,

Жизнь, зачем ты мне дана? 
Иль зачем судьбою тайной

Ты на казнь осуждена?

Кто меня враждебной властью

Из ничтожества воззвал,

Душу мне наполнил страстью,

Ум сомненьем взволновал?...

Цели нет передо мною:

Сердце пусто, празден ум,

И томит меня тоскою

Однозвучный жизни шум".

Опять слово д-ру Далю:

"Вообще был он - по крайней мере в обращении со мною, повадлив и послушен, как ребенок, и делал все, о чем я его просил.

(С вечера) с обеда пульс был крайне мал, слаб и част - после полуночи стал он подыматься, а к 6-му часу ударял не более 120 в минуту и стал полнее и тверже. В то же время начал показываться небольшой общий жар. Вследствие полученных от д-ра Арендта наставлений приставили мы с д-ром Спасским 25 пиявок и в то же время и (послали) за Арендтом. Он приехал и одобрил распоряжение наше. Больной наш твердою рукою сам ловил и припускал себе пиявки и неохотно позволял нам около себя копаться. Пульс стал ровнее, реже и гораздо мягче; я ухватился, как утопленник, за соломинку, робким голосом провозгласил надежду и обманул было и себя, и других - но ненадолго. Пушкин заметил, что я был подобрее, взял меня за руку и спросил: "Никого тут нет?" - "Никого", - отвечал я. "Даль, скажи же мне правду, скоро ли я умру?" - "Мы за тебя надеемся, Пушкин", - сказал я, - "право надеемся!" Он пожал мне крепко руку и сказал: "Ну спасибо!". Но, по-видимому, он однажды только и обольстился моею надеждою: ни прежде, ни после этого он не верил ей, спрашивал нетерпеливо: "Скоро ли конец", - и прибавлял еще: "Пожалуйста, поскорее!". В продолжение долгой, томительной ночи глядел я с душевным сокрушением на эту таинственную борьбу жизни и смерти".

\section{Врачебная хроника.}

Om 12 часов дня и дальше. Руки остыли по самые плечи. Резкое изменение дыхания: частое отрывистое сменяется протяжным. Состояние полудремоты, "забытья". Чувство головокружения. Спутанность сознания. Зрительные галлюцинации. Просветления с ясным сознанием. Жалобы на чувство давления в груди; трудно дышать.

Вот слова Данзаса:

"Поутру 29-го января он несколько раз призывал жену. Потом пожелал видеть Жуковского и говорил с ним довольно долго наедине. Собравшиеся в это утро доктора нашли Пушкина уже совершенно в безнадежном положении, а приехавший затем Арендт объявил, что Пушкину осталось жить не более двух часов". 
Доктор Спасский:

"Рано утром 29-го числа я к нему возвратился. Пушкин истаевал. Руки были холодны, пульс едва заметен. Он беспрестанно требовал холодной воды и брал ее в малых количествах, иногда держал во рту небольшие куски льда и от времени до времени сам тер себе виски и лоб льдом. Доктор А. подтвердил мои и Д. Д. опасения. Около 12 часов больной спросил зеркало, посмотрел в него и махнул рукою. Он неоднократно приглашал к себе жену".

Весть о ранении Пушкина разнеслась по Петербургу. У дома Пушкина постоянно стояла толпа людей. По воспоминаниям современников, 29-го января подъезд с утра был атакован публикой до такой степени, что Данзас должен был обратиться в Преображенский полк с просьбою поставить у крыльца часовых, чтобы восстановить какой-нибудь порядок: густая масса собравшихся загораживала на большое расстояние все пространство перед квартирой Пушкина, к крыльцу почти не было возможности протискаться.

Между тем Пушкину делалось все хуже, он, видимо, слабел с каждым мгновением. Друзья его: Жуковский, князь Вяземский с женой, князь Петр Иванович Мещерский, А. И. Тургенев, г-жа Загряжская, Даль и Данзас были у него в кабинете.

Вспоминает доктор Спасский:

"Незадолго до смерти ему захотелось морошки. Наскоро послали за этой ягодой. Он с большим нетерпением ее ожидал и несколько раз повторял: морошки, морошки. Наконец привезли морошку. "Позовите жену", - сказал Пушкин, - "пусть она меня кормит". Он съел 2-3 ягодки, проглотил несколько ложечек соку морошки, сказал: "Довольно", - и отослал жену. Лицо его выражало спокойствие. Это обмануло несчастную его жену; выходя она сказала мне: "Вот увидите, что он будет жив, он не умрет". Но судьба определила иначе".

А это - Данзас:

"До последнего вздоха Пушкин был в совершенной памяти, перед самой смертью ему захотелось морошки. Данзас сейчас же за нею послал, и, когда принесли, Пушкин пожелал, чтоб жена покормила его из своих рук, ел морошку с большим наслаждением и после каждой ложки, подаваемой женою, говорил:

- Ах, как это хорошо!

Когда этот болезненный припадок аппетита был удовлетворен, жена Пушкина вышла из кабинета. В отсутствие ее началась агония, она была почти мгновенна".

Снова доктор Спасский:

"Минут за пять до смерти Пушкин просил поворотить его на правый бок. Даль, Данзас и я исполнили его волю: слегка поворотили его и под- 
ложили к спине подушку. "Хорошо", - сказал он, и потом несколько погодя промолвил, - "жизнь кончена!" - "Да, конечно", - сказал доктор Даль, - "мы тебя поворотили". - "Кончена жизнь", - возразил тихо Пушкин. Не прошло несколько мгновений, как Пушкин сказал: "Теснит дыхание". То были последние его слова".

И, наконец, Даль:

"Пульс стал упадать приметно и вскоре исчез вовсе. Руки начали стыть. Ударило два часа по полудни 29-го января, и в Пушкине оставалась жизнь только на 3/4 часа. Бодрый дух все еще сохранял могущество свое - изредка только полудремотное забвение на несколько секунд туманило мысли и душу. Тогда умирающий несколько раз подавал мне руку, сжимал ее и говорил: "Ну подымай же меня, пойдем, да выше, выше - ну пойдем!" Опамятовавшись, сказал он мне: "Мне было пригрезилось, что я с тобой лезу вверх по этим книгам и полкам, высоко - и голова закружилась". Немного погодя он опять, не раскрывая глаз, стал искать мою руку и, потянув ее, сказал: "Ну пойдем же, пожалуйста, да вместе!".

Друзья и ближние молча, сложа руки, окружили изголовье отходящего".

Не эти ли сцены словно бы предвосхитил Пушкин в стихотворении "На выздоровление Лукулла", когда он писал:

"Ты угасал, богач младой!

Ты слышал плач друзей печальных

Уж смерть являлась за тобой

В дверях сеней твоих хрустальных.

Она, как втершийся с утра

Заимодавец терпеливый,

Торча в передней молчаливой

Не трогалась с ковра.

В померкшей комнате твоей

Врачи угрюмые шептались..."

Правда, в этом стихотворении все закончилось хорошо.

"...Ты воскрес. Твои друзья,

В ладони хлопая, ликуют...

Бодрится врач, подняв очки...

Так жизнь тебе возвращена

Со всею прелестью своею".

В жизни Пушкина все получилось, к сожалению, иначе.

Снова доктор Даль:

"Я по просьбе его взял его под мышки и приподнял повыше. Он вдруг, будто проснувшись, быстро раскрыл глаза, лицо его прояснилось, и он сказал: "Кончена жизнь". Я не дослышал и спросил тихо: "Что кончено?". "Жизнь кончена", - отвечал он внятно и положительно. "Тяжело дышать, 
давит", - были последние слова его. Всеместное спокойствие разлилось по всему телу - руки остыли по самые плечи, пальцы на ногах, ступни, колена также; отрывистое, частое дыхание изменялось более и более на медленное, тихое, протяжное - еще один слабый, едва заметный вздох - и пропасть необъятная, неизмеримая разделяла уже живых от мертвого!"

29 января 1837 г. в 2 часа 45 минут наступила смерть....

Contra vim mortis non est medicamentum in hortis - против силы смерти нет средства в садах.

Пушкин умер. Как сказал поэт Владимир Одоевский, "солнце нашей поэзии закатилось".

А через несколько дней российское общество было взбудоражено стихами молодого Михаила Лермонтова. В стихотворении "На смерть поэта" Лермонтов писал:

"Погиб поэт! Невольник чести -

Пал, оклеветанный молвой,

С свинцом в груди и жаждой мести,

Поникнув гордой головой!..."

Здесь все верно - и про невольника чести, и про клевету молвы, и про жажду мести. Неверно лишь о свинце в груди: как оказалось на вскрытии, свинец был не в груди, а в животе.

Вскрытие тела проводил И. Т. Спасский - он был еще и судебным медиком. Ему помогал доктор Даль. Они же подписали протокол вскрытия.

Вот, что писал Даль:

"Вскрытие трупа показало, что рана принадлежала к безусловно смертельным."

От чего же погиб Пушкин, можно ли было его спасти?

Вот диагнозы его состояния. Вслед за ранением свинцовой пулей в живот у Пушкина развилось легкое сотрясение мозга, затем кратковременный шок. Возникшее в начале послераневой болезни коллаптоидное состояние перешло в коллапс (резкое острое снижение кровяного давления, угнетение центральной нервной системы) с периодами относительной "компенсации". Затем последовало кровотечение.

У Пушкина развился к концу первых суток (приблизительно) перитонит, который был клиническим проявлением изменений в зоне ранения. По механизму развития это был травматический ("травматогенный") перитонит, а по клиническому течению - "анемичный" перитонит, протекавший на фоне резкого малокровия.

В общем, получилось почти так, как писал Пушкин в "Похоронной песне" (из цикла "Песни западных славян"):

"С Богом, в дальнюю дорогу!

Путь найдешь ты, слава Богу.

Светит месяц; ночь ясна; 


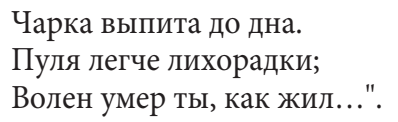

Только в этот раз пуля оказалась не легче, а страшнее лихорадки, когда-то терзавшей Пушкина в течение нескольких лет: пуля оказалась смертельной.

Правильным ли было лечение раненого поэта?

На этот вопрос отвечали многие ученые-медики и врачи.

Первую врачебную помощь раненому Пушкину оказывали Шольц и Задлер. Они смотрели рану на передней брюшной стенке, констатировали внутреннее кровотечение, установили, что из наружной раны кровотечение незначительно; клали на живот холодные компрессы; давали больному холодное питье.

Итак, горизонтальное положение, покой плюс холод - разумная для того времени терапия при внутреннем кровотечении в брюшной полости.

В течение ночи с 27 на 28 января в лечении каких-либо перемен не последовало. Боль в животе все нарастала, становилась нестерпимой.

Врачей можно упрекнуть лишь в том, что они не пользовали больного опием - единственным "противоболевым" средством, бывшим в их распоряжении. Оно, конечно же, не могло снять боли, обусловленной развивающейся раневой болезнью, но благодаря наркотическому действию способно было уменьшить остроту боли, доведшей Пушкина до попытки самоубийства. Наибольшая ответственность лежит на дежурившем в эту ночь И. Т. Спасском, который, очевидно, воздерживался от назначения опия по той причине, что больной находился между жизнью и смертью и опий мог усугубить и ускорить летальный исход.

В промежуток от 4 до 6 часов утра 28-го января состояние больного ухудшилось. Врачи предприняли "промывательное": это вмешательство усугубило тяжелое состояние Пушкина. Произошла "суммация боли" из всех больных органов. Пушкин впал в шоковое состояние: у него возник рефлекторный болевой шок.

Таким образом по своей травмирующей силе "промывательное" было равнозначно второму ранению, учитывая исходное состояние Пушкина ко времени применений очистительной клизмы (острое малокровие, болевое истощение). Только через 6-7 часов больной несколько успокоился.

Однако это не было врачебной ошибкой. Так называемое "промывательное" - одно из классических средств против многих болезней, широко распространенное тогда во всей Европе.

Что касается пиявок, то их использование было одним из видов кровопускания ("кровобросания"), а кровопускание оставалось в первой половине XIX века наиболее распространенным средством лечения почти всех заболеваний. К тому же лечение перитонита "приставлением пиявок к страж- 
дущему месту" - животу - было общепринятым для того времени методом лечения, хотя врачи понимали, что перитонит в то время был смертельной болезнью.

К сказанному добавлю, что в 1937 г., к 100-летию со дня смерти Пушкина, специальная комиссия пришла к выводу, что проведенное Арендтом лечение раненого Пушкина для своего времени было безупречным.

Однако в одном, все-таки, Арендта, а также Шольца, можно упрекнуть: они сказали своему пациенту Пушкину, что рана его смертельна. С точки зрения деонтологии и врачебной этики это далеко не бесспорный поступок.

Что же можно сказать в заключение?

У постели раненого Пушкина находился цвет российской медицины и хирургии первой половины XIX века (Н. Ф. Арендт, И. В. Буяльский, Х. Х. Саломон, И. Т. Спасский, Е. И. Андреевский и др.). Не было только Н. И. Пирогова, жившего в то время в Дерпте. Все эти ученые и опытные врачи владели всеми последними достижениями медицины того времени.

На вопрос, правильно ли лечили Пушкина, следует единственный ответ: лечение проводилось классическими способами медицины и хирургии первой половины XIX века.

Будь Пушкин ранен в наши дни, и сейчас нельзя было бы категорически говорить о возможности его исцеления. Даже по самой оптимистической статистике, число летальных исходов после ранений, подобных пушкинскому, равно 10-20 процентам.

По авторитетному мнению выдающегося российского хирурга академика Б. В. Петровского, сегодня даже при самых благоприятных условиях оказания доврачебной помощи и доставки раненого в квалифицированное хирургическое учреждение рана Пушкина должна быть названа очень тяжелой, а исход травмы в 30-40\% - неблагоприятным.

К сожалению, даже современная медицина не дает, по-видимому, полной гарантии выздоровления после такого опасного ранения.

....Пушкин не мечтал о долгой жизни. Вот его строки (1836):

"Пошли мне долгу жизнь и многие годы!"

Зевеса вот о чем и всюду и всегда

Привыкли вы молить - но сколькими бедами

Исполнен долгий век!"

И, однако, ему же принадлежат написанные приблизительно тогда другие строки:

"О нет, мне жизнь не надоела,

Я жить люблю, я жить хочу,

Душа не вовсе охладела,

Утратя молодость свою". 
Словно предчувствуя близкую гибель, в августе 1836 г. Пушкин написал свой знаменитый "Памятник" - вольный перевод Горация. Там есть такие строки, оказавшиеся пророческими:

"Нет, весь я не умру - душа в заветной лире

Мой прах переживет и тленья убежит -

И славен буду я, доколь в подлунном мире

Жив будет хоть один пиит...".

Да, это пророческие строки!...

\section{Литература}

1. Бурденко Н. Н., Арендт А. А., Была ли смертельна рана Пушкина? Литературная газета, № 7, 1939, 5 февраля.

2. Лукьянов С. М. О последних днях жизни и смерти А. С. Пушкина с медицинской точки зрения.//Известия Отделения русского языка А Н. T. IV, кн. 3. Санкт-Петербург: 1899.

3. Малис Ю. Г. Болезнь и смерть А. С. Пушкина. Петроград: 1915.

4. Пушкин в воспоминаниях современников. Москва: 1950.

5. Пушкин А. С. Полное собрание сочинений в десяти томах. Москва: 1956-1958.

6. Русский биографический словарь. Под редакцией А. А.Половцева. СанктПетербург: 1900-1914.

7. Терновский В. Н. Последние дни А. С. Пушкина. Красная Татария, № 32, 1937, 9 февраля.

8. Удерман Ш. И. Избранные очерки истории отечественной хирургии ХІХ столетия. Ленинград: 1970.

9. Шаак В. А. Ранение А. С. Пушкина. Вестник хирургии, № 52, 1937.

10. Щеголев П. Е. Дуэль и смерть Пушкина. Изд. 3. Ленинград: 1928.

11. Юдин С. С. Ранение и смерть Пушкина. Правда, 1937, 8 февраля.

\section{Injury and death of Aleksandr Pushkin (Summary)}

\section{By Mark B. Mirsky}

The author describes in detail, hour after hour, describes the health of Pushkin after the severe injury sustained in the duel. Relying on literature sources the author names the doctors that took care of the dying poet, judging by that they were the best at that time. He compares the healing methods of that time with the methods of today and if it would be possible to save a person today, with such 
a severe injury as Pushkin had. The author admits that even in the 21 st century doctors could not assure a recovery from such an injury. The article also features several memories from the doctors about the last minutes of Pushkin. It also features some prophetic poesy, as seen by the author, by Aleksandr Pushkin.

Марк Борисович Мирский, профессор

Национальный НИИ общественного здоровья РАМН, Москва

Prof. Dr. med. Mark B. Mirsky 